\title{
Development of the Greywater Domestic Treatment Unit for Irrigation of the Garden in Rural Areas
}

\author{
Ali Hadi Ghawi ${ }^{1}$ \\ 1 University of Al-Qadisiyah, Collage of Engineering, Department of Road and Transport Engineering, Iraq, \\ e-mail: ali.ghawi@qu.edu.iq
}

\begin{abstract}
Greywater is an important water resource at the household level. The reuse of greywater is one of the most promising ways of conserving water because it has an important role in increasing plant productivity at the garden level. It is an important option to increase the efficiency of water use at the household level in rural Iraq. Through the implementation of a greywater treatment unit, this project sought to develop the treatment technology and encourage the local community in the target areas to reuse it. In this study, a greywater treatment unit that consists of a septic tank, up-flow anaerobic filter, and a storage tank is constructed on a specified area in the Khairi village in Al Diwaniyah province in Iraq. In order to ensure the quality of the treated greywater used in irrigation, an experimental verification and analysis of results were performed to demonstrate the improvement of physical, chemical and biological parameters. These parameters are COD, BOD, and TSS. According to the results of the study, the anaerobic filter (Subsurface Flow) was designed with one septic tank and three compartments. The total removal efficiency of COD, BOD, and TSS by greywater treatment unit was $92.27 \%, 96.9 \%$, and $99.0 \%$, respectively. The quality of the water produced by the greywater treatment unit was consistent with the FAO guidelines for reuse of treated water to irrigate domestic gardens.
\end{abstract}

Keywords: greywater; irrigation; water recycle; treatment unit

\section{INTRODUCTION}

At present, water scarcity is the main problem faced by the central and southern regions of Iraq. This may be due to both natural and human factors. Many reports indicate that water scarcity is due to anthropogenic factors such as irrigation, domestic use, etc., as well as global warming and poor water management. All of these anthropogenic and environmental factors led to the scarcity of surface water, reduced groundwater levels, and the amount of pollutants in water has increased rapidly (UNESCO, 2015).

At present, Iraq suffers from water scarcity and the problem of water scarcity is exacerbated by the increase in the number of the population, so that the per capita water supply will be reduced annually if new water sources are not provided. This in turn prompts decision makers to seek unconventional water sources, including greywater, for irrigation in environmentally safe ways. Since the problems of the agricultural sector are a difficult task for the decision makers in Iraq under the current water shortage conditions of the low share of the agricultural sector of water and increased demand for water to other sectors, it became necessary to use all available water resources, including low-quality water sources to address these challenges (Al-Ansari et al., 2014).

To this day, there is no water culture in the central and southern Iraq to manage and regulate the use of water for various domestic and public uses and irrigation of gardens. Because the rural areas in the central and southern Iraq do not have networks or irrigation systems for the house gardens, most of the houses use a drinking water network to irrigate the gardens (IAU 2010). Therefore, it has become necessary to find other sources of water to prevent the water shortages in these areas. In order to remedy this situation, a greywater 
treatment unit was designed and implemented under the garden soil of a certain house located in the Khairi village Al Diwaniyah city, Iraq, to purify the drained greywater from this house.

This unit consists of a septic tank and anaerobic filters containing gravel media of different sizes on which the anaerobic bacteria grow.

There is still a lack of studies on the greywater reuse in Iraq. Moreover, most of the previous studies consisted of the design and implementation of a laboratory scale greywater treatment units.

These studies included the laboratory experiments that were carried out by Zaidun 2011, who implemented a laboratory filtration system for the treatment of greywater. The impact of hydraulic load on the efficiency of the filtration system was examined. He found that the highest removal efficiency of BOD was $83 \%$. The most advanced technology used in the world for the treatment of domestic wastewater and greywater is the membrane technology of the bioreactor. However, the technology is very expensive and difficult to implement in developing countries (Varma et al., 2017).

In this study, the greywater drainage system was separated from the drainage system (Figure 1). The technique of anaerobic filters was used to treat the greywater from rural houses and reuse it in the irrigation of domestic gardens. There are many recent studies on the technique of using anaerobic filters for the treatment of sewage and greywater in households, hotels, schools and hospitals. These studies include the study by Al-Mashaqbeh et al., 2012, who investigated the possibility of reusing greywater in rural Jordan. The results of their study showed that the people in the study area were willing to accept the reuse of greywater in order to ensure their water needs for irrigation due to the severe shortage of water resources.

The researchers who studied the design of anaerobic filters in the treatment of greywater and sanitation in markets, hospitals and residential houses are Praditya 2013, Rakhmadany 2013, Mahatyanta, and Razif 2016 respectively, who demonstrated the efficiency of this system in the treatment of sewage and greywater. Chaabane et al., 2017 also studied the use of anaerobic filters of various media types for the treatment of greywater such as siliceous sand/marble waste. In Iraq, two new studies have been done by Ghawi: In 2017 to reuse greywater and black water in garden irrigation and Ghawi, 2018 in which he recommended the application of anaerobic filters to reuse greywater in gardens of rural area. This greywater treatment system in the countryside is very suitable, because it is a highly efficient, easy to implement solution. Thus, we have performed a more detailed study to obtain the best efficiency

The previous studies showed the efficiency of the anaerobic filters use in the treatment of greywater. On the basis of the previous studies, an anaerobic filter for the treatment of greywater was designed and implemented for a residential house in the village of Khairi in the city of Diwaniyah. The current study aims at planning, designing, developing and implementing a greywater treatment system in low-cost rural areas (The "septic tank-Bioreactor") to address the problems of rural water scarcity and the reuse of greywater in the irrigation of domestic gardens.

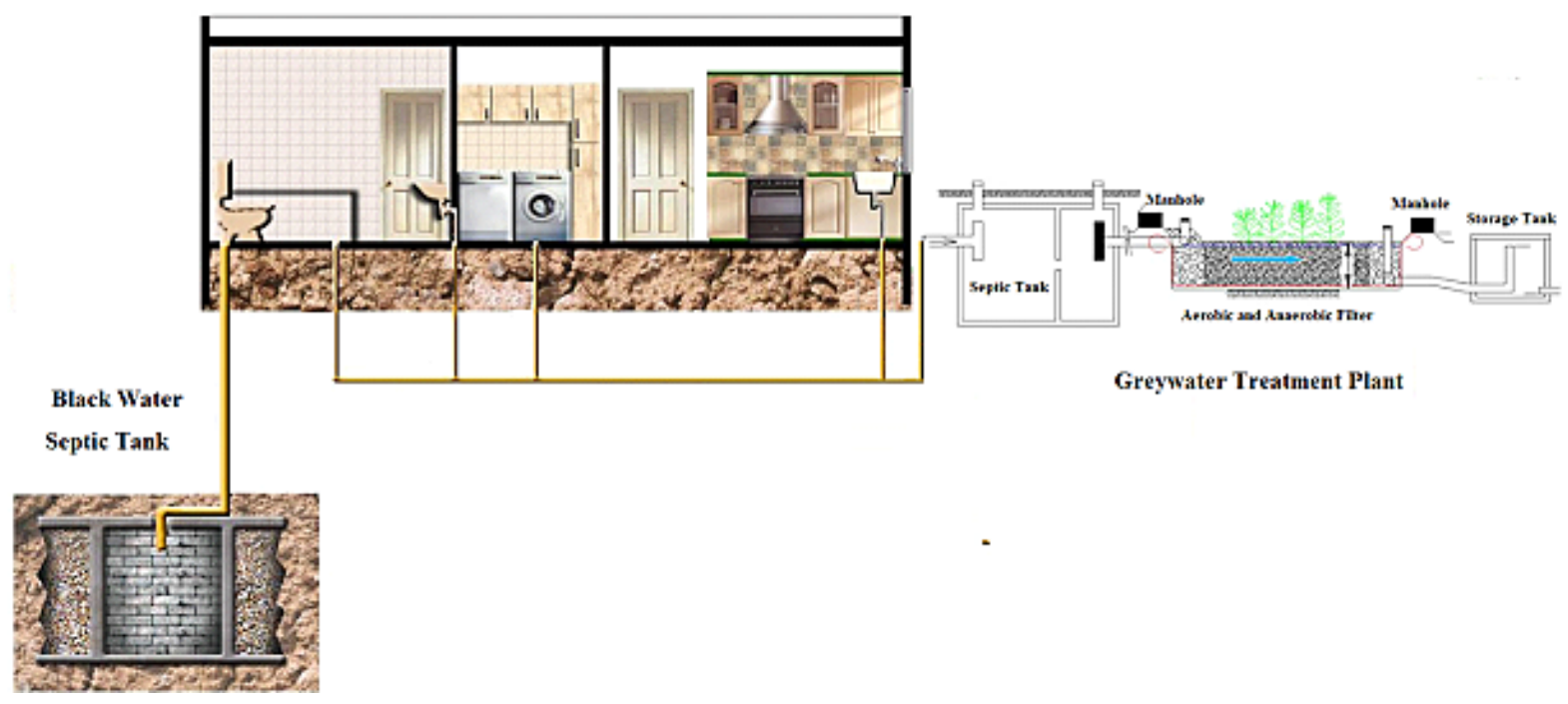

Figure 1. A proposal for the management of rural effluents at the household level 


\section{MATERIAL AND METHODS}

\section{Advantage of Anaerobic Filter} (Subsurface Flow) and Site Study

There are many advantages to using anaerobic filters in household greywater treatment such as: high efficiency and reliability, high processing efficiency, hydraulic and organic shock load resistance, slightly formed sludge, unnecessary microorganisms, no electrical power needed to run. The filtration media are available and cheap, easy to operate and maintain, and do not require large areas to be carried out and implemented under the soil of the garden home. For these reasons, the anaerobic filter system was designed and employed in this study. The greywater treatment unit was implemented in the village of Khairi in the countryside of Al Diwaniyah, one of the southern cities of Iraq and the Middle Euphrates region, about $180 \mathrm{~km}$ from Baghdad (Figures 2 and 3).

The design of the greywater treatment unit depends on the quality and quantity of greywater coming out of the laundries, bathtubs, washing machines and floor drains (Juan et al. 2016). The quantity of greywater produced from houses was provided by Al Diwaniyah Sewage Directorate, where the quantities of greywater produced daily in the Iraqi countryside with a water distribution network range from 150-160 liters per person. These quantities vary from house to house and depend on the standard of living and the customs related to the use of water. For example, a house with a self-contained washing machine produces more greywater than a house that uses a handheld washing machine. This amount is significantly reduced when the house satisfies its water

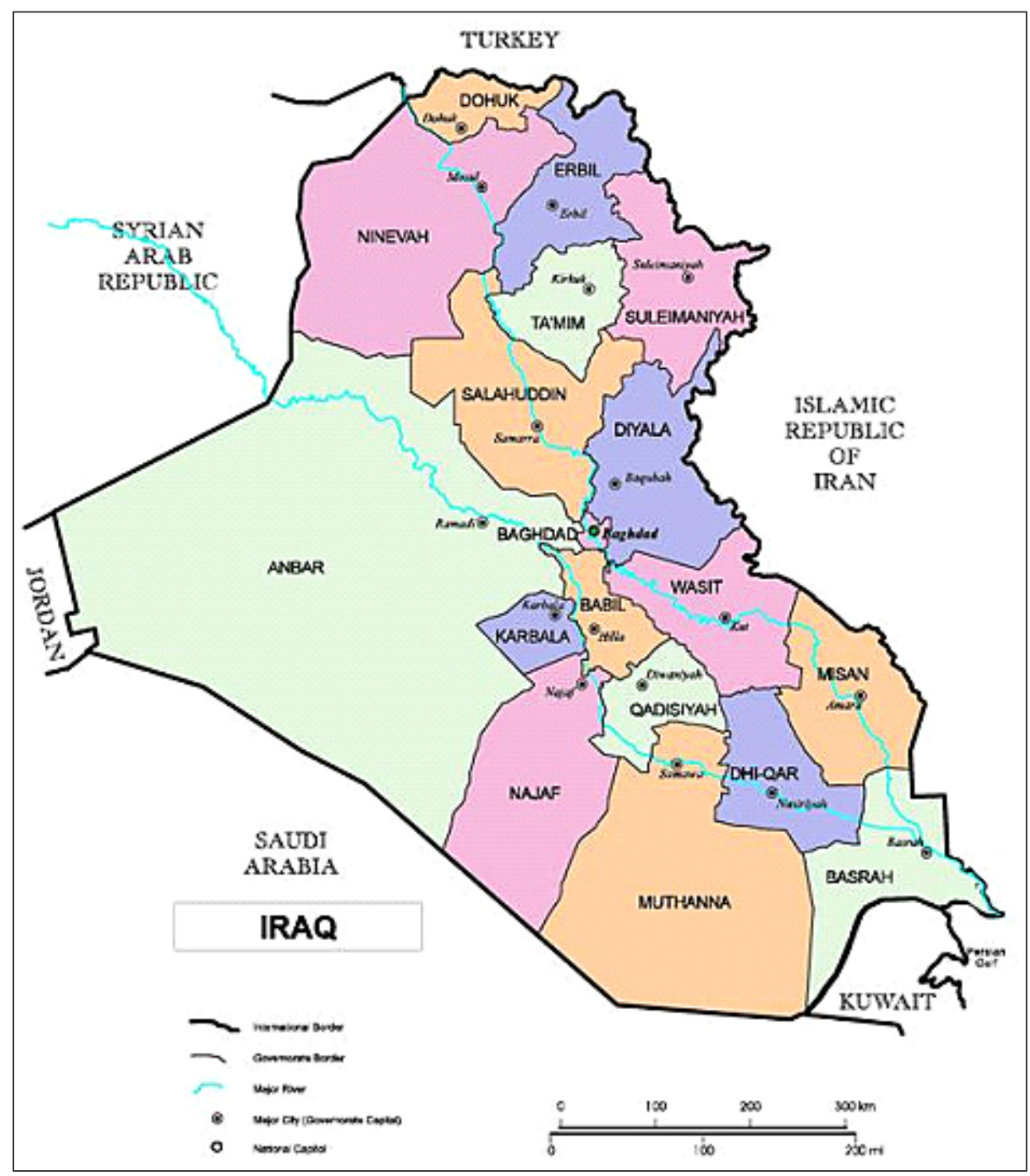

Figure 2. Administrative map of Iraq and the location of Al-Qadisiyah Governorate 


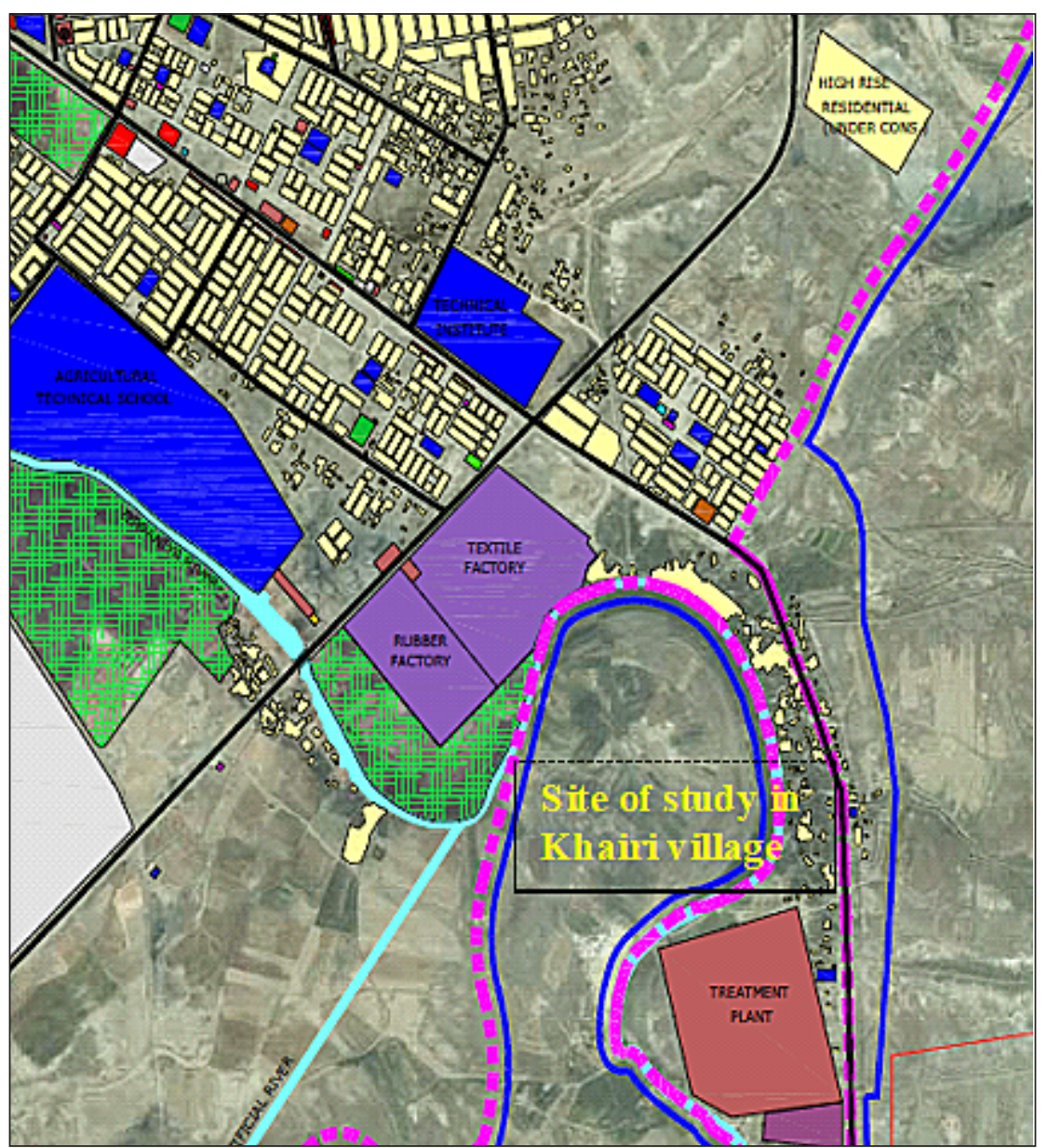

Figure 3. Site of study in Khairi village

needs from a tap outside the house or from a river. The amount used in the same house varies from day to day and from season to season.

In all cases, the greywater is cleaner than black wastewater considering all pollutants except fats and oils (Von Sperling et al., 2005). In this study, the Food and Agriculture Organization of the United Nations (FAO) guidelines for treated greywater were adopted to assess the quality of the treated water used in garden irrigation as shown in Table 1 (Jaramillo and Restrepo 2017).

The treatment system for greywater was implemented in a house with an area of $600 \mathrm{~m}^{2}$ and the area of the garden is $200 \mathrm{~m}^{2}$ and 8 residents. Laboratory tests on untreated greywater showed the high concentration of BOD, COD, and the increase in the number of fecal coliform bacteria, which necessitates upgrading the treatment system used to obtain agricultural water quality for irrigating the garden without causing harm to public health or any other element of the environment. Therefore, many of the previous greywater treatment systems that have been used in different countries of the world have been reviewed. The study focused on the development of wetlands technology and on improving the design of this system in order to obtain the best quality and quantity of greywater.

\section{Greywater Sampling}

The greywater samples for raw and treated grey water were collected in 2017. The parameters measured for the samples at the study site and in the Al-Diwaniyah Environment Directorate Laboratories included Temperature, $\mathrm{pH}$, Total Biochemical Oxygen Demand (BOD), Total Chemical Oxygen Demand (COD), Total suspended solids (TSS), Color, Odor, E.Coli /100ml bacteria, Heavy Metal, Soil Salinity (EC), Sodium Adsorption Ratio (SAR), and Total Coliform $/ 100 \mathrm{ml}$ bacteria. The analysis was carried out according to the standard method for examination of water and wastewater (APHA, 2005). 
Table 1. FAO guidelines for the agricultural reuse of treated water

\begin{tabular}{|c|c|c|}
\hline Type of Agricultural Reuse & Type of Treatment & Quality Criterion \\
\hline $\begin{array}{l}\text { Agricultural reuse in crops that } \\
\text { are consumed and not processed } \\
\text { commercially. }\end{array}$ & $\begin{array}{l}\text { secondary } \\
\text { filtration - disinfection }\end{array}$ & $\begin{array}{c}\mathrm{pH}=6.5-8.4 \\
\mathrm{BOD}<10 \mathrm{mg} / \mathrm{L} \\
<2 \mathrm{UNT} \\
<14 \mathrm{NMP} \text { E. coli/100 mL } \\
<1 \mathrm{Egg} / \mathrm{L}\end{array}$ \\
\hline $\begin{array}{l}\text { Agricultural reuse in crops that } \\
\text { are consumed and not processed } \\
\text { commercially. }\end{array}$ & secondary - disinfection & $\begin{array}{c}\mathrm{pH}=6.5-8.4 \\
\mathrm{BOD}<30 \mathrm{mg} / \mathrm{L} \\
\mathrm{SS}<30 \mathrm{mg} / \mathrm{L} \\
<200 \mathrm{NMP} \text { E. coli } / 100 \mathrm{~mL}\end{array}$ \\
\hline $\begin{array}{l}\text { Agricultural reuse in crops that are not } \\
\text { consumed. }\end{array}$ & secondary - disinfection & $\begin{array}{c}\mathrm{pH}=6.5-8.4 \\
\mathrm{BOD}<30 \mathrm{mg} / \mathrm{L} \\
\mathrm{SS}<30 \mathrm{mg} / \mathrm{L} \\
<200 \mathrm{NMP} \text { E. coli } / 100 \mathrm{~mL}\end{array}$ \\
\hline
\end{tabular}

\section{Design criteria and hydraulic design}

The design of anaerobic filter is equipped with a septic tank (sedimentation). The septic tank is used for settling discrete particles that can clog the aerobic and anaerobic filter. Tables 2 and 3 and the hydraulic design equations below show the criteria used in this study to design the greywater treatment unit at the household level (EPA, 2009).

Hydraulics design equations are applied to the greywater treatment system in rural households shown below (EPA, 2009):

1 . The temperature-dependent rate constant is calculated from the rate constant for $20^{\circ} \mathrm{C}$ and the correction factor of 1.1. The rate constant $\mathrm{K}_{\mathrm{T}}$ $\left(\right.$ in $\left.\mathrm{d}^{-1}\right)$ at water temperature $\mathrm{T}\left({ }^{\circ} \mathrm{C}\right)$ can therefore be defined by Equation 1 (EPA, 2009).

$$
\mathrm{KT}=\mathrm{K} 20(1.1) \mathrm{T}-20
$$

2. The cross sectional area for flow through a subsurface flow system is calculated according to the Equation 2:

$$
\mathrm{Ac}=\mathrm{Q} / \mathrm{Ks} \mathrm{S}
$$

where $A_{C}=\mathrm{d} * \mathrm{~W}$, cross-sectional area of wetland bed, perpendicular to the direction of flow, $\mathrm{m}^{2}$

$d=$ bed depth, $\mathrm{m}$

$R=$ bed width, $\mathrm{m}$

$k_{s}=$ hydraulic conductivity of the medium, $\mathrm{m}^{3} / \mathrm{m}^{2}-\mathrm{d}$

$S=$ slope of the bed, or hydraulic gradient

Table 2. Design criteria of sedimentation tank

\begin{tabular}{|c|l|c|}
\hline No. & \multicolumn{1}{|c|}{ Parameter } & Rang \\
\hline 1 & Detention time (hours) & $1-2$ \\
\hline 2 & Surface loading rate $\left(1 / \mathrm{hr} / \mathrm{m}^{2}\right)$ & $500-750$ \\
\hline 3 & Depth of tank $(\mathrm{m})$ & $0.6-1.0$ \\
\hline 4 & Length to width ratio & $3: 1$ to $4: 1$ \\
\hline
\end{tabular}

3. The bed width is calculated by the Equation 3 .

$$
\mathrm{W}=\mathrm{Ac} / \mathrm{d}
$$

4. Removal of $\mathrm{BOD}_{5}$ (Determine the surface area) in subsurface flow systems can be described in Equation 4.

$$
\mathrm{As}=[\mathrm{Q}(\mathrm{In} \mathrm{Co}-\mathrm{In} \mathrm{Ce})] \div\left(\mathrm{K}_{\mathrm{T}} \mathrm{d} \mathrm{n}\right)
$$

where, $C_{e}=$ effluent $\mathrm{BOD}_{5}, \mathrm{mg} / \mathrm{L}$

$C_{o}=$ influent $\mathrm{BOD}_{5}, \mathrm{mg} / \mathrm{L}$

$K_{T}=$ temperature-dependent first-order reaction rate constant, $\mathrm{d}^{-1}$

$Q=$ average flow rate through the system, $\mathrm{m}^{3} / \mathrm{d}$

$d=$ depth of submergence, $\mathrm{m}$

$n=$ porosity of the bed, as a fraction

5. Determine the bed length $(\mathrm{L})$ and the detention time ( $(\mathrm{t})$ in the system (Equation 5 and 6).

$$
\begin{gathered}
\mathrm{L}=\mathrm{As} / \mathrm{W}) \\
\mathrm{t}=\mathrm{L} \mathrm{W} \mathrm{d} \mathrm{n} / \mathrm{Q} \text { ) }
\end{gathered}
$$

\section{RESULTS AND DISCUSSION}

\section{Greywater treatment unit process}

A subsurface flow system was developed in the project. The treatment units were designed based on the environmental data of the site, the quality of the water discharged from the houses and the quality of the water required to effluent the treatment system. The system included three stages of treatment:

1. Septic Tank

2. Aerobic and Anaerobic Filter (Subsurface Flow)

3. Storage Tank 
Table 3. Design criteria of aerobic and anaerobic filter (subsurface flow)

\begin{tabular}{|c|l|c|}
\hline No. & \multicolumn{1}{|c|}{ Parameter } & Rang \\
\hline 1 & Number of compartments & $3-4$ \\
\hline 2 & Media and size $(\mathrm{mm})$ & $\begin{array}{c}\text { course rock (128) } \\
\text { fine gravel }(16) \\
\text { medium gravel (32) } \\
\text { course sand (2) } \\
\text { gravelly sand (8) }\end{array}$ \\
\hline 3 & Hydraulic loading rate $\left(1 / \mathrm{m}^{2}\right.$ per dose) & 8 max. \\
\hline 4 & Depth of media $(\mathrm{m})$ & $0.4-0.6$ \\
\hline 5 & Capacity in population equivalent (person) & Up to 8 \\
\hline 6 & Rate of water supply $(\mathrm{l} / \mathrm{person} /$ day) & 150 \\
\hline 7 & Area required $\left(\mathrm{m}^{2} / \mathrm{p} . \mathrm{e}\right)$ & $1.5-3$ \\
\hline 8 & Minimum system size $\left(\mathrm{m}^{2}\right)$ & 15 \\
\hline 9 & Length $/$ width ratio & $2.5: 1$ \\
\hline
\end{tabular}

The development of greywater treatment system required studying several natural factors and relying on the following preliminary information:

- The nature of the water expected to enter the system and the required water specifications of effluent water from the system.

- BOD concentration in the treated water.

- Temperature rate for winter and summer season.

- The quantity of water expected to be processed daily.

On the basis of the design limitations shown in Table 2 and Table 3, the greywater treatment system design process was adopted as follows:

- 1 - Depth of Aerobic and Anaerobic Filter (Subsurface Flow) assumed as 40-50 cm.

- 2 -Adoption of $1 \%$ slope for basins.

- 3 - Selection of the size of the filtration media (gravel).

Table 4 shows the effect of filter media size used on the removal efficiency of BOD, COD, TSS, and E. Coli / MPN / $100 \mathrm{ml}$. When using fine gravel of 4-8 $\mathrm{mm}$ for filtration and then use coarse gravel of $10-20 \mathrm{~mm}$, the results show that the smaller the size of the gravel the more efficient the removal of pollutants. Thus, the size of the gravel $(20 \mathrm{~mm}$, and $8 \mathrm{~mm})$ was chosen for second and third basins, respectively, which gives the best design.

The house greywater flowed into the sedimentation basin (septic tank). The greywater was fermented by gravity so that the greywater was poured close to the bottom of it. In this part of the system, deposition of solids and the separation of fat occur by the special structure of the tubes that prevents fat from going into the next basin, and bacteria active in this part reduce the sulfur, which is necessary to decompose a lot of chemicals such as washing powder, and shampoos (Figure 4).

The water is moved to the second basin, which contains gravels with the size of $20-40 \mathrm{~mm}$ which grow bacteria that feed on organic matter and turn it into raw materials, energy and gases, including carbon dioxide and methane. The water naturally flows to the third basin, which also contains gravel with the size of 5-20 $\mathrm{mm}$. The only difference between the two basins is that the first basin contains large-size pores. It is not closed by the sediments and bacterial masses resulting from the high concentration of organic matter in this basin. This leads to the natural cleaning of the bacteria, which makes their number always limited.

Table 4. Effect of filter grain size on efficiency of treatment

\begin{tabular}{|l|l|c|c|}
\hline \multicolumn{1}{|c|}{ Parameter } & \multicolumn{1}{|c|}{ Media size (mm) } & Before Treatment & After Treatment \\
\hline \multirow{2}{*}{ BOD mg/L } & course gravel (10-20) & 320 & 25.8 \\
\cline { 2 - 4 } & fine gravel (4-8) & 320 & 9.9 \\
\hline \multirow{2}{*}{ COD mg/L } & course gravel (10-20) & 409 & 85.5 \\
\cline { 2 - 4 } & fine gravel (4-8) & 409 & 41.8 \\
\hline \multirow{2}{*}{ E.Coli / MPN/100 ml } & course gravel (10-20) & 43 & $0.20 \% \mathrm{per} \mathrm{ml}$ \\
\cline { 2 - 4 } & fine gravel (4-8) & 43 & $96 \mathrm{mg} / \mathrm{ml}$ \\
\hline \multirow{2}{*}{ TSS } & course gravel (10-20) & $350 \mathrm{mg} / \mathrm{l}$ & $3 \mathrm{mg} / \mathrm{l}$ \\
\cline { 2 - 4 } & fine gravel (4-8) & $350 \mathrm{mg} / \mathrm{l}$ & \\
\hline
\end{tabular}




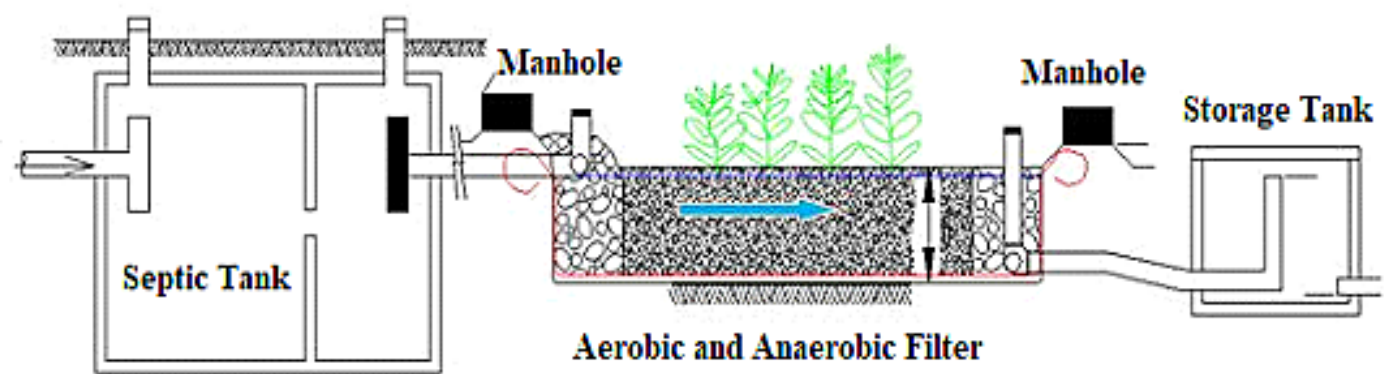

Figure 4. The greywater treatment unit

In the third basin, the concentration of organic matter is small and the surface that bacteria can use is large. The spaces do not close and there is a greater chance of getting rid of the rest of the organic matter. Water is also naturally transferred to the fourth basin and it is for storage only.

All this process is carried out in the absence of air (anaerobic) and therefore the water collected in the fourth basin is free of dissolved air and contains suspended substances forming decomposing substances and bacteria. The gases resulting from the activity of the bacteria in the system are discharged into the air by a system of pipes that collects these gases and is directed to the outside of the station. The water produced by this system is suitable for irrigating the house garden where treated water can be used by irrigation system suitable for the irrigation of tree plantations or plants that are eaten and cooked in the garden of the house (Figure 5).

\section{The quality of the greywater}

In order to ensure the quality of treated greywater used in irrigation, a periodic water monitoring program was implemented before entering the treatment unit and after treatment. The samples were collected twice each month over a year and in Table 5 the average sampling was taken for six months. The laboratory testing rate was adopted for only two months as the highest and lowest values observed in this study. Table 5 shows the results of biological, physical and chemical analysis of the most important criteria. The total removal efficiencies of greywater treatment unit are: SAR $10 \%$, Ca 11\%, Mg 9\%, Na 33\%, E.Coli 90\%, COD 92.27\%, BOD 96.9\%, and TSS 99.0\%. These values indicate the high efficiency of the treatment units with the high or low percentage of water pollution entering them.

The standard for the use of greywater in irrigation specifies the $\mathrm{BOD}$ concentration of

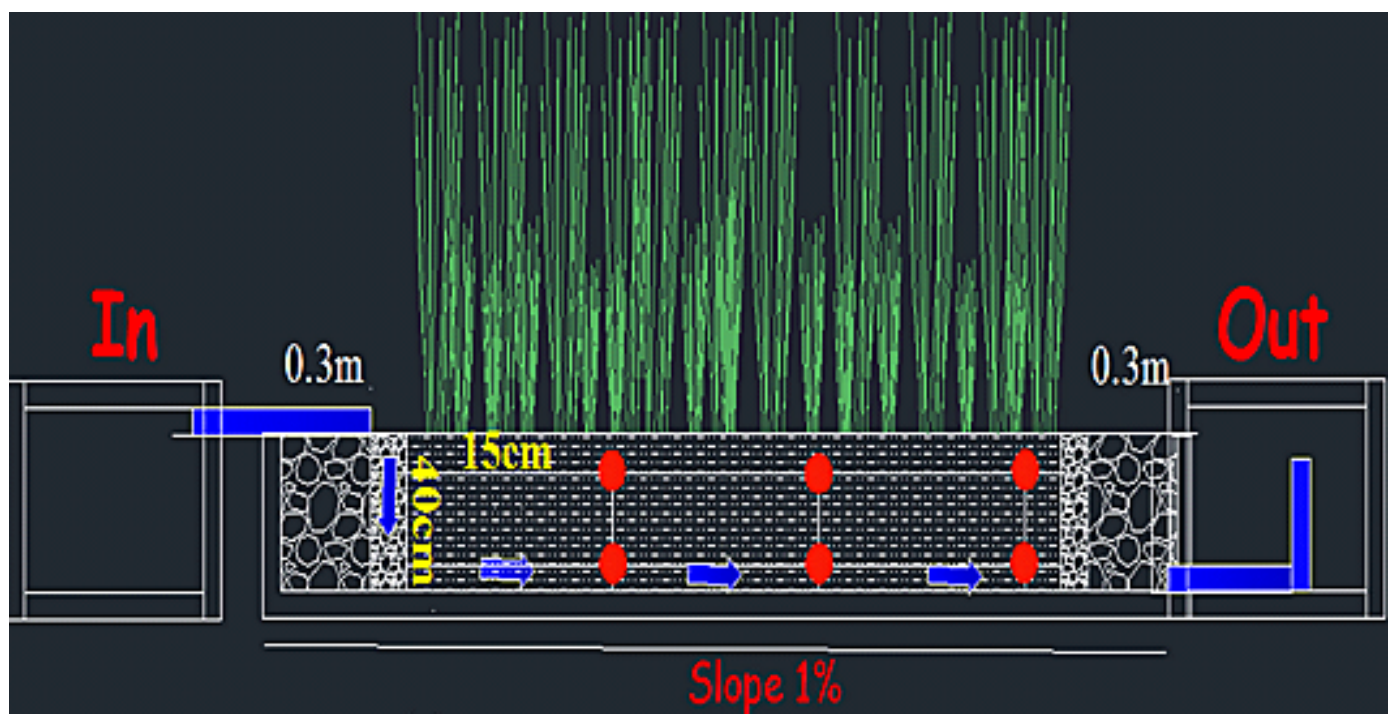

Figure 5. Vertical section of the greywater treatment unit $(0.1 \mathrm{~m}$ fine gravel and 0.3 course gravel) 
Table 5. Results of physical, biological and chemical analyses of water

\begin{tabular}{|c|c|c|c|}
\hline Month & Parameter & Before Treatment & After Treatment \\
\hline \multirow{16}{*}{ January 2017} & BOD mg/L & 300 & 8.04 \\
\hline & COD mg/L & 411 & 42.0 \\
\hline & E.Coli / MPN/100 ml & 45 & $0.20 \%$ per ml \\
\hline & Total Coliform/ MPN/100 ml & 135 & $0.30 \%$ per $\mathrm{ml}$ \\
\hline & Temperature & $10^{\circ} \mathrm{C}$ & $20^{\circ} \mathrm{C}$ \\
\hline & TSS & $380 \mathrm{mg} / \mathrm{l}$ & $4 \mathrm{mg} / \mathrm{l}$ \\
\hline & Color & Black & No color \\
\hline & Odor & Foul gas & Odorless \\
\hline & $\mathrm{pH}$ & 7.1 & 6.8 \\
\hline & $\mathrm{EC}(\mathrm{dS} / \mathrm{m})$ & 0.86 & 0.82 \\
\hline & SAR (meq/L) & 1.67 & 1.60 \\
\hline & $\mathrm{Ca}(\mathrm{meq} / \mathrm{L})$ & 3.8 & 2.89 \\
\hline & $\mathrm{Mg}(\mathrm{meq} / \mathrm{L})$ & 2.95 & 2.87 \\
\hline & $\mathrm{Na}(\mathrm{meq} / \mathrm{L})$ & 2.97 & 2.73 \\
\hline & Cd (ppm) & $0.0019>$ & $0.0019>$ \\
\hline & $\mathrm{Pb}(\mathrm{ppm})$ & $0.009>$ & $0.009>$ \\
\hline \multirow{16}{*}{ March 2017} & BOD mg/L & 288 & 9.2 \\
\hline & COD mg/L & 349 & 26.1 \\
\hline & E.Coli / MPN/100 ml & 41 & $0.20 \%$ per $\mathrm{ml}$ \\
\hline & Total Coliform/ MPN/100 ml & 132 & $0.30 \%$ per $\mathrm{ml}$ \\
\hline & Temperature & 18 & $22^{\circ} \mathrm{C}$ \\
\hline & TSS & $412 \mathrm{mg} / \mathrm{l}$ & $4.9 \mathrm{mg} / \mathrm{l}$ \\
\hline & Color & Black & No colour \\
\hline & Odor & Foul gas & Odourless \\
\hline & $\mathrm{pH}$ & 7.1 & 6.7 \\
\hline & $\mathrm{EC}(\mathrm{dS} / \mathrm{m})$ & 0.91 & 0.80 \\
\hline & SAR (meq/L) & 1.78 & 1.56 \\
\hline & $\mathrm{Ca}(\mathrm{meq} / \mathrm{L})$ & 1.99 & 1.82 \\
\hline & $\mathrm{Mg}(\mathrm{meq} / \mathrm{L})$ & 3.51 & 3.20 \\
\hline & $\mathrm{Na}(\mathrm{meq} / \mathrm{L})$ & 3.28 & 2.16 \\
\hline & $\mathrm{Cd}(\mathrm{ppm})$ & $0.0019>$ & $0.0019>$ \\
\hline & $\mathrm{Pb}(\mathrm{ppm})$ & $0.009>$ & $0.009>$ \\
\hline \multirow{16}{*}{ May 2017} & $\mathrm{BOD} \mathrm{mg} / \mathrm{L}$ & 320 & 9.9 \\
\hline & COD mg/L & 409 & 41.8 \\
\hline & E.Coli / MPN/100 ml & 43 & $0.20 \%$ per $\mathrm{ml}$ \\
\hline & Total Coliform/ MPN/100 ml & 132 & $0.30 \%$ per $\mathrm{ml}$ \\
\hline & Temperature & $22^{\circ} \mathrm{C}$ & $22^{\circ} \mathrm{C}$ \\
\hline & TSS & 350 mg/l & $3 \mathrm{mg} / \mathrm{l}$ \\
\hline & Color & Black & No color \\
\hline & Odor & Foul gas & Odorless \\
\hline & $\mathrm{pH}$ & 7.5 & 6.9 \\
\hline & $E C(d S / m)$ & 0.84 & 1.09 \\
\hline & SAR (meq/L) & 1.62 & 1.78 \\
\hline & $\mathrm{Ca}(\mathrm{meq} / \mathrm{L})$ & 3 & 2.69 \\
\hline & $\mathrm{Mg}(\mathrm{meq} / \mathrm{L})$ & 2.90 & 2.89 \\
\hline & $\mathrm{Na}(\mathrm{meq} / \mathrm{L})$ & 2.92 & 3.03 \\
\hline & $\mathrm{Cd}(\mathrm{ppm})$ & $0.0019>$ & $0.0019>$ \\
\hline & $\mathrm{Pb}(\mathrm{ppm})$ & $0.009>$ & $0.009>$ \\
\hline
\end{tabular}


Table 5. cont.

\begin{tabular}{|c|c|c|c|}
\hline Month & Parameter & Before Treatment & After Treatment \\
\hline \multirow{16}{*}{ July 2017} & BOD mg/L & 343 & 9.5 \\
\hline & COD mg/L & 423 & 28.3 \\
\hline & E.Coli / MPN/100 ml & 50 & $0.20 \%$ per $\mathrm{ml}$ \\
\hline & Total Coliform/ MPN/100 ml & 140 & $0.30 \%$ per $\mathrm{ml}$ \\
\hline & Temperature & $20^{\circ} \mathrm{C}$ & $22^{\circ} \mathrm{C}$ \\
\hline & TSS & $409 \mathrm{mg} / \mathrm{l}$ & $4 \mathrm{mg} / \mathrm{l}$ \\
\hline & Color & Black & No colour \\
\hline & Odor & Foul gas & Odourless \\
\hline & $\mathrm{pH}$ & 7.1 & 6.7 \\
\hline & $E C(d S / m)$ & 0.95 & 0.81 \\
\hline & SAR (meq/L) & 1.9 & 1.77 \\
\hline & $\mathrm{Ca}(\mathrm{meq} / \mathrm{L})$ & 1.92 & 1.78 \\
\hline & $\mathrm{Mg}(\mathrm{meq} / \mathrm{L})$ & 3.50 & 3.11 \\
\hline & $\mathrm{Na}(\mathrm{meq} / \mathrm{L})$ & 3.00 & 2.00 \\
\hline & Cd (ppm) & $0.0019>$ & $0.0019>$ \\
\hline & $\mathrm{Pb}(\mathrm{ppm})$ & $0.009>$ & $0.009>$ \\
\hline \multirow{16}{*}{ September 2017} & BOD mg/L & 254 & 7.8 \\
\hline & COD mg/L & 343 & 24.8 \\
\hline & E.Coli / MPN/100 ml & 46 & $0.20 \%$ per $\mathrm{ml}$ \\
\hline & Total Coliform/ MPN/100 ml & 125 & $0.30 \%$ per $\mathrm{ml}$ \\
\hline & Temperature & $20^{\circ} \mathrm{C}$ & $22^{\circ} \mathrm{C}$ \\
\hline & TSS & $400 \mathrm{mg} / \mathrm{l}$ & $4 \mathrm{mg} / \mathrm{l}$ \\
\hline & Color & Black & No colour \\
\hline & Odor & Foul gas & Odourless \\
\hline & $\mathrm{pH}$ & 7.1 & 6.7 \\
\hline & $\mathrm{EC}(\mathrm{dS} / \mathrm{m})$ & 0.90 & 0.82 \\
\hline & SAR (meq/L) & 1.9 & 1.72 \\
\hline & $\mathrm{Ca}(\mathrm{meq} / \mathrm{L})$ & 1.92 & 1.90 \\
\hline & $\mathrm{Mg}(\mathrm{meq} / \mathrm{L})$ & 3.55 & 3.21 \\
\hline & $\mathrm{Na}(\mathrm{meq} / \mathrm{L})$ & 3.25 & 2.16 \\
\hline & $\mathrm{Cd}(\mathrm{ppm})$ & $0.0019>$ & $0.0019>$ \\
\hline & $\mathrm{Pb}(\mathrm{ppm})$ & $0.009>$ & $0.009>$ \\
\hline \multirow{16}{*}{ November 2017} & BOD mg/L & 311 & 6.9 \\
\hline & COD mg/L & 341 & 24.1 \\
\hline & E.Coli / MPN/100 ml & 47 & $0.20 \%$ per $\mathrm{ml}$ \\
\hline & Total Coliform/ MPN/100 ml & 127 & $0.30 \%$ per $\mathrm{ml}$ \\
\hline & Temperature & $20^{\circ} \mathrm{C}$ & $22^{\circ} \mathrm{C}$ \\
\hline & TSS & $407 \mathrm{mg} / \mathrm{l}$ & $4.4 \mathrm{mg} / \mathrm{l}$ \\
\hline & Color & Black & No colour \\
\hline & Odor & Foul gas & Odourless \\
\hline & $\mathrm{pH}$ & 7.0 & 6.9 \\
\hline & $\mathrm{EC}(\mathrm{dS} / \mathrm{m})$ & 0.87 & 0.79 \\
\hline & SAR (meq/L) & 1.9 & 1.82 \\
\hline & $\mathrm{Ca}(\mathrm{meq} / \mathrm{L})$ & 1.88 & 1.80 \\
\hline & $\mathrm{Mg}(\mathrm{meq} / \mathrm{L})$ & 3.55 & 3.21 \\
\hline & $\mathrm{Na}(\mathrm{meq} / \mathrm{L})$ & 3.29 & 2.12 \\
\hline & $\mathrm{Cd}(\mathrm{ppm})$ & $0.0019>$ & $0.0019>$ \\
\hline & $\mathrm{Pb}(\mathrm{ppm})$ & $0.009>$ & $0.009>$ \\
\hline
\end{tabular}


$10 \mathrm{mg} / \mathrm{l}$. For this reason, the water discharged from the treatment unit is in accordance with the FAO standard and can be used for irrigation. The owners of the house were advised to comply with the instructions of the management of the unit and to adhere to the quality of waste coming out of the kitchen sink. Table 5 shows that greywater before treatment is highly saturated with fecal coliform bacteria and total coliform bacteria. The numbers of these bacteria decreased after treatment. Laboratory tests also showed no foul odours from the treatment unit, as well as the absence of impurities. The bacteria concentrations were within the limitations, so there was no need to conduct disinfection of the resulting water.

As for the control of chemical changes in greywater before and after treatment, the results of the analyses were shown in Table 5 where it is noted that:

- Increasing the salinity and water of the water out of the system was compared to the access to it due to the availability of sodium element on the surface of filter media or from groundwater. The results also show that the concentration of sodium decreases gradually with the use of the treatment unit and therefore salinity takes the same trend with decreasing time.

- Greywater, treated or untreated, has no trace of cadmium and lead, the two most important heavy elements likely to be presentingreywater.

- The use of grey treated water to irrigate the garden can be accepted from a social and cultural point of view

\section{CONCLUSION}

There is a need to treat greywater and use it in agriculture as a result of the acute shortage of available potable water. The reuse of treated water will reduce the consumption of potable water, especially used in irrigation of the garden and eliminates the need for composting because of its efficiency in the treated greywater. Experimental verification and analysis of results were performed to demonstrate the improvement of physical, chemical and biological properties. Thus, the implementation of anaerobic filters reduces the demand of water. Since the construction of this greywater treatment unit is easy and economical, it can be implemented and used in developing countries. The total removal efficiency of greywater treatment unit is: COD $92.27 \%$, BOD $96.9 \%$, and TSS $99.0 \%$. The quality of the water produced by the greywater treatment unit was consistent with the FAO guidelines for the agricultural reuse of treated water to irrigate domestic gardens.

\section{REFERENCES}

1. Al-Ansari N., Ali A.A., Knutsson S. 2014. Present Conditions and Future Challenges of Water Resources Problems in Iraq. Journal of Water Resource and Protection, 6, 1066-1098.

2. Al-Mashaqbeh O.A., Ghrair A.A., Megdal S.N. 2010. Grey Water Reuse for Agricultural Purposes in the Jordan Valley: Household Survey Results in Deir Alla. Water, 4, 580-596; doi:10.3390/w4030580.

3. Anand Kumar Varma S., Sangavi R., Pavithra K., 2017. Development of a Bio-reactor septic tank for Domestic waste water treatment. International Journal of ChemTech Research, 10(12), 189-201.

4. APHA, 2005. Standard Methods for The Examinations of Water and Wastewater. 21st ed. Washington, DC: American Public Health Association.

5. Chaabane S., Riahi K., Hamrouni H., Thayer B.B. 2017. Suitability assessment of grey water quality treated with an upflow-downflow siliceous sand/marble waste filtration system for agricultural and industrial purposes. Environ Sci Pollut Res Int. 24(11), 9870-9885. doi: 10.1007/s11356-016-7471-X.

6. EPA, 2009. Code of Practice: Wastewater Treatment and Disposal Systems Serving Single Houses. Environmental Protection Agency, Johnstown Castle Estate, Wexford, Ireland.

7. Ghawi A.H. 2017. Study of the Reuse of Greywater in the Irrigation of the Home Garden in Rural Areas. Journal of Engineering And Applied Sciences, 12 (26), 7944-7950.

8. Ghawi A.H. 2018. Study on the Development of Household Wastewater Treatment Unit. Journal of Ecological Engineering, 19 (2), 63-71.

9. IAU - Inter-Agency Information and Analysis Unit. Water in Iraq Factsheet. October 2010.

10. Jaramillo M.F. and Restrepo I., 2017. Wastewater Reuse in Agriculture: A Review about Its Limitations and Benefits. Sustainability, 9, 1734, doi:10.3390/su9101734.

11. Mahatyanta A. and Razif M. 2016. Alternative Design of Wastewater Treatment Plant with Anaerobic Baffled Reactor and Anaerobic Filter for Romokalisari Flats Surabaya. International Journal of ChemTech Research, 9(11), 195-200.

12. Praditya A. 2013 Alternative Design of Wastewater Treatment at Mall by Aerobic, Anaerobic and the 
Combination of Anaerobic and Aerobic Processess in Surabaya City. Final Project on Department of Environmental Engineering ITS Surabaya.

13. Rakhmadany A. 2013. Alternative Design of Wastewater Treatment at Hospital by Aerobic, Anaerobic and the Combination of Anaerobic and Aerobic Processess in Surabaya City. Final Project on Department of Environmental Engineering ITS Surabaya.

14. UNESCO 2015. The United Nations World Water Development Report 2015. Published by the United Nations Educational, Scientific and Cultural Organization, 7, place de Fontenoy, 75352
Paris 07 SP, France.

15. Von Sperling M. and Chernicharo C.A.L. 2005. Biological Wastewater Treatment in Warm Climate Regions. IWA Publishing, London, pp. 835.

16. Yi-Kai Juan, Yi Chen and Jing-Ming Lin 2016. Greywater Reuse System Design and Economic Analysis for Residential Buildings in Taiwan. Water, 8(11), 546; doi:10.3390/w8110546.

17. Zaidun N.A. 2011. The Effect Of Sand Filter Characteristics On Removal Efficiency Of Organic Matter From Grey Water. Al-Qadisiya Journal for Engineering Sciences, 4(2). 